Vol. 2, No. 1, Juni 2021

\title{
SPEKTA
}

Jurnal Pengabdian Kepada Masyarakat : Teknologi dan Aplikasi

Journal homepage :

http://journal2.uad.ac.id/index.php/spekta

\section{PENGOLAHAN LIMBAH MINYAK JELANTAH MENJADI LILIN AROMATERAPI DI BANK SAMPAH LINTAS WINONGO, KELURAHAN BUMIJO, KECAMATAN JETIS, KOTA YOGYAKARTA}

\author{
Amalia Yuli Astuti ${ }^{1, *}$, Utaminingsih Linarti ${ }^{2}$, Gita Indah Budiarti ${ }^{3}$ \\ 1,2Program Studi Teknik Industri, Universitas Ahmad Dahlan, Bantul, Daerah Istimewa Yogyakarta, Indonesia \\ ${ }^{3}$ Program Studi Teknik Kimia, Universitas Ahmad Dahlan, Bantul, Daerah Istimewa Yogyakarta, Indonesia
}

\begin{tabular}{l}
\hline ARTICLE INFO \\
\hline \\
Received : February, 2021 \\
Revised : March, 2021 \\
Accepted : April, 2021 \\
\hline
\end{tabular}

Keywords:

Waste Cooking Oil;

Waste Bank;

Recycled Products;

Aromatherapy Candles.

\begin{abstract}
Waste Cooking Oil (WCO) is the waste that came from household. WCO become a threat to community because it will come back to food chains again as residual bulk oil that have cheaper price than branded cooking oil. Lintas Winongo Waste Bank in Bumijo, Jetis, Yogyakarta City are trying to manage the waste cooking oil into recycled products. One of their products is aromatherapy candles. However, they had problem to produce the candles and sell it. They also faced problem about the odor of candle that came from WCO as raw material. The purpose of community service were to provide knowledge and skills to produce aromatherapy candles and to calculate the Cost of Goods Sold (CoGS). The methods in this activity were carried out in two stage. The first activity has organized by training and assistance in producing aromatherapy candles that mixed WCO and other ingredients. The second activity focused in calculating CoGS of candles. The results from these community service activities were increased knowledge and skills about producing aromatherapy candles. There were also increased knowledge about manage CoGS of their products.
\end{abstract}

\section{PENDAHULUAN}

Minyak jelantah merupakan salah satu jenis limbah yang dihasilkan dari proses pengolahan makanan dengan minyak goreng. Limbah ini dapat berasal dari rumah tangga, warung, restoran maupun bisnis makanan lainnya. Minyak jelantah dihasilkan dari proses pengolahan bahan pangan dengan minyak goreng. Pada saat terjadi proses penggorengan

\footnotetext{
* Corresponding author.

E-mail address: amalia.yuliastuti@ie.uad.ac.id

https://doi.org/10.12928/J.spekta.v2i1.3701
} 
Vol. 2, No. 1, Juni 2021

terjadi tiga reaksi degradasi yaitu hidrolisis yang menghasilkan free fatty acid, oksidasi, dan polimerisasi (Sanli, Canakci, \& Alptekin, 2011).

Limbah minyak jelantah memberikan ancaman pada manusia jika digunakan kembali untuk mengolah bahan pangan. Terdapat kasus di mana minyak jelantah masuk ke restoran yang ada di Taiwan pada tahun 2014 yang menjadi permasalahan besar pada keamanan makanan (Tsai, 2019; Wee, Budiman, Su, Chang, \& Chen, 2016). Badan Pengawas Obat dan Makanan (BPOM) Indonesia mencurigai adanya pihak-pihak tertentu yang menjadi pengumpul minyak jelantah dan menjualnya kembali dalam bentuk minyak goreng curah (Saragih, 2015). Ancaman minyak jelantah yang dapat masuk kembali ke rantai makanan dapat memberikan dampak buruk pada kesehatan. Kandungan free fatty acid di minyak jelantah dapat meningkatkan risiko beberapa penyakit di antara diabetes dan kanker (Artwohl, Roden, Waldhäusl, Freudenthaler, \& Baumgartner-Parzer, 2004; Kuo \& Ann, 2018; Lupi et al., 2002; Madak-Erdogan et al., 2019; Oh, Bae, Baek, Park, \& Jun, 2018).

Minyak jelantah juga dapat menjadi sumber pencemaran lingkungan baik di saluran air, sungai atau waduk. Pencemaran air yang diakibatkan oleh minyak jelantah dapat merusak ekosistem yang ada di waduk atau sumber air lainnya (Azahar et al., 2016). Selain itu minyak jelantah yang mengalir ke sumber air maupun waduk dapat menutupi lapisan permukaan air yang menyebabkan sinar matahari tidak tembus ke dalam air dan merusak lingkungan hidup biota air (Azahar et al., 2016).

Jumlah minyak jelantah yang dihasilkan setiap rumah tangga diperkirakan ada sekitar empat liter per bulan. Perkiraan ini berdasarkan data dari rumah tangga di wilayah Jabodetabek yang menghasilkan minyak jelantah kurang lebih satu liter setiap minggu (Vanessa \& Bouta, 2017). Data ini menunjukkan bahwa jumlah minyak jelantah yang dihasilkan cukup besar. Jika di sebuah kota terdapat sekitar 200.000 kepala keluarga maka diperkirakan volume minyak jelantah ada sekitar 800.000 liter per bulan. Konfirmasi mengenai ke mana minyak jelantah tersebut berakhir belum dapat dipastikan namun terdapat pemetaan jaringan minyak jelantah di kota Yogyakarta. Bentuk jaringan pengelolaan minyak jelantah di kota Yogyakarta sudah terpetakan sampai pada pabrik yang membutuhkan campuran minyak jelantah dengan bahan bakar diesel untuk pembakaran (Astuti, Linarti, \& Yulistiyanto, 2019).

Bank sampah sebagai salah satu organisasi mempunyai peran dalam mengurangi jumlah sampah yang dihasilkan dari aktivitas rumah tangga (Budiyanto, Astuti, \& Purwani, 2020). Jenis sampah yang dikelola bank sampah bermacam-macam, salah satunya adalah minyak jelantah. Pengelolaan limbah minyak jelantah ini belum optimal dikarenakan kemampuan dan pengetahuan yang dimiliki oleh bank sampah pada jenis limbah ini masih kurang. Di Kota Yogyakarta, terdapat satu bank sampah yang aktif mengelola limbah ini dengan memproduksinya menjadi produk recycled.

Pengolahan minyak jelantah menjadi lilin sudah terdapat beberapa artikel yang memuat program tersebut. Terdapat program pembuatan lilin aromaterapi dari minyak jelantah di Dusun Sorowajan, Pedukuhan Glugo, Desa Pangungharjo, Kecamatan Sewon, Kabupaten Bantul (Wardani, Saptutyningsih, \& Fitri, 2021). Selain itu terdapat program yang sama dilakukan di Desa Tirtonirmolo Kasihan, Rogocolo, Bantul (Jamilatun, Mulia Sitophyta, Amelia Universitas Ahmad Dahlan, Ringroad Selatan, \& Banguntapan, 2020). Program untuk memanfaatkan minyak jelantah ditemukan pula di Desa Pelalan, Kecamatan Lamasi Timur, Kabupaten Luwu (Delta, 2021). Di Dusun Jetak Desa Bolon Kecamatan Colomadu Karanganyar, minyak jelantah diolah menjadi lilin berwarna warni (Sundoro, Kusuma, \& Auwalani, 2020). Di Kota Batu, minyak jelantah dimanfaatkan 
Vol. 2, No. 1, Juni 2021

menjadi lilin ramah lingkungan (Aini, Arisanti, Fitri, \& Safitri, 2020). Pemanfaatan minyak jelantah tidak hanya sebatas lilin aromaterapi namun juga untuk lilin hias di Kelurahan Pantai Amal (Adhani \& Fatmawati, 2017). Namun, belum ada program pengabdian untuk pengolahan minyak jelantah menjadi lilin aromaterapi di Bank Sampah Lintas Winongo, Kelurahan Bumijo, kecamatan Jetis, Kota Yogyakarta. Bank sampah Lintas Winongo adalah salah satu bank sampah yang mengolah limbah minyak jelantah. Pihak bank sampah sudah berupaya untuk mengolah limbah tersebut menjadi lilin.

Produksi lilin mengalami beberapa kendala di antaranya adalah lilin masih mempunyai bau kurang sedap. Lilin yang dihasilkan mempunyai bau di mana bau tersebut berasal dari bahan baku minyak jelantah. Bau tersebut disebabkan kandungan free fatty acid dalam minyak jelantah (Tsai, 2019). Permasalahan lain yang dihadapi oleh bank sampah Lintas Winongo adalah keuntungan dari produksi lilin belum diperoleh. Pengetahuan pengelola bank sampah tidak mengetahui cara untuk mendapatkan keuntungan dengan menetapkan Harga Pokok Produksi (HPP). Pengelola bank sampah menentukan harga produk lilin berdasarkan pada harga pasaran produk secara umum tanpa melihat aspek biaya-biaya dalam produksi lilin. Kedua permasalahan bank sampah tersebut menjadi fokus pada aktivitas pengabdian kepada masyarakat ini.

Berdasarkan permasalahan yang dihadapi bank sampah Lintas Winongo, pengabdian kepada masyarakat ini mempunyai tujuan untuk memberikan pelatihan dan pendampingan dalam produksi lilin aromaterapi dari minyak jelantah. Pelatihan untuk memproduksi lilin aromaterapi dengan bahan-bahan yang dapat mengurangi bau serta memberikan bentuk lilin yang lebih baik daripada sebelumnya. Kemudian diberikan pula pelatihan dan pendampingan untuk mengkalkulasi HPP untuk produk lilin. Pelatihan HPP memberikan pengetahuan baru agar pihak bank sampah tidak hanya menetapkan harga produk berdasarkan intuisi saja namun bisa menggunakan dasar kalkulasi yang dipertimbangkan dengan seksama.

\section{METODE PELAKSANAAN}

Aktivitas pada pengabdian kepada masyarakat ini dilakukan dengan metode pelatihan dan pendampingan kepada bank sampah Lintas Winongo di kelurahan Bumijo, kecamatan Jetis, Kota Yogyakarta. Pelatihan dan pendampingan dilakukan secara langsung di lapangan dalam dua tahap di mana tahap pertama fokus pada pengolahan minyak jelantah menjadi lilin aromaterapi dan tahap kedua berfokus pada kalkulasi HPP terhadap produk lilin. Peserta dari pelatihan dan pendampingan ini adalah 12 sampai 14 orang anggota dari bank sampah Lintas Winongo. Setiap tahap dari pelatihan dan pendampingan tersebut didahului oleh persiapan terlebih dahulu kemudian ditutup dengan evaluasi pelaksanaan. Pada setiap tahapan pelatihan terdapat pre-test dan posttest yang diberikan pada peserta sebelum pelatihan (pre-test) dan setelah pelatihan (posttest).

Pada pelatihan pengolahan minyak jelantah membutuhkan beberapa alat dan bahanbahan untuk membuat lilin. Alat yang digunakan untuk pelatihan pengolahan minyak jelantah adalah panci, pengaduk, sendok, wadah kaca untuk lilin, kompor dan gas. Bahan yang diperlukan adalah minyak jelantah, stearin, parfum aromaterapi, krayon bekas, dan tali rami. Praktek pelatihan dilaksanakan pada lokasi bank sampah Lintas Winongo. Pelatihan pengolahan minyak jelantah dilaksanakan dengan melibatkan dua orang mahasiswa di mana mahasiswa ini membantu untuk memberikan materi pelatihan. Kedua mahasiswa tersebut merupakan anggota kelompok keahlian yang sudah memiliki kemampuan praktek untuk mengolah minyak jelantah menjadi beberapa produk recycled. 
Vol. 2, No. 1, Juni 2021

Pada tahap pelatihan ini dilaksanakan transfer pengetahuan mengenai teknologi yang terkait dengan pengolahan minyak jelantah menjadi lilin aromaterapi. Pengetahuan mengenai teknologi pengolahan yang diberikan kepada peserta merupakan teknologi yang mudah untuk diaplikasikan.

Pelatihan dan pendampingan tahap kedua mengenai HPP dilaksanakan pula pada lokasi bank sampah Lintas Winongo. Pelaksanaan dilakukan dengan pemberian materi pelatihan dengan diikuti pendampingan untuk menentukan HPP lilin aromaterapi. Pemberian materi dilakukan oleh anggota tim pelaksana pengabdian kepada masyarakat sesuai keahliannya.

\section{HASIL DAN PEMBAHASAN}

Aktivitas pengabdian kepada masyarakat terbagi menjadi dua tahapan di mana pada tahap pertama adalah pelatihan dan pendampingan mengenai pengolahan minyak jelantah menjadi lilin aromaterapi. Pelatihan ini menggunakan alat-alat dan bahan yang sudah disiapkan. Jumlah peserta yang mengikuti kegiatan tahap pertama adalah 12 orang dari anggota bank sampah Lintas Winongo. Sesi dalam pelatihan terbagi menjadi dua bagian. Bagian pertama dilakukan pemberian materi pengolahan minyak jelantah menjadi lilin. Proses yang dilakukan adalah memanaskan minyak jelantah, stearin sebanyak lima sendok makan dan rayon sambil diaduk hingga mendidih. Lalu dicampurkan parfum aromaterapi sesuai kebutuhan. Setelah semua tercampur, menuangkan adonan lilin aromaterapi ke wadah kaca dan mendiamkannya sampai setengah dingin. Terakhir, memasang sumbu lilin dan menunggu adonan mengeras (Budiarti, Wulandari, \& Mutmaina, 2020).

Pada saat pelatihan pembuatan minyak menjadi lilin terdapat sesi diskusi mengenai proses dalam pengolahan. Beberapa pertanyaan dari peserta adalah mengenai proses yang dulu pernah dilakukan dan mengenai bahan-bahan subtitusi ke lilin jika tidak menemukan bahan sesuai pelatihan ini. Sebelum dilaksanakannya pelatihan, peserta diberikan kuesioner pre-test mengenai pengetahuan yang dipunyai sebelumnya. Kemudian dilanjutkan pemberian kuesioner post-test setelah pelatihan selesai. Hasil dari pengolahan kuesioner pre-test dan post-test dapat dilihat pada Tabel 1. Kuesioner yang dibuat menggunakan skala Likert dengan empat rentang nilai dari tidak setuju, netral, setuju dan sangat setuju.

Tabel 1. Pengolahan Item Pertanyaan pada Kuesioner Pre-test dan Post-test Pelatihan Tahap Pertama dan Kedua

\begin{tabular}{|c|c|c|c|}
\hline No & Item Pertanyaan & $\begin{array}{l}\text { Rata-Rata } \\
\text { (Tahap 1) }\end{array}$ & $\begin{array}{l}\text { Rata-Rata } \\
\text { (Tahap 2) }\end{array}$ \\
\hline \multicolumn{4}{|c|}{ Kuesioner Pre-test } \\
\hline 1 & $\begin{array}{l}\text { Sebelum mengikuti pelatihan ini, saya } \\
\text { mengetahui hal-hal berkaitan dengan langkah- } \\
\text { langkah dalam pelatihan (Pengetahuan } \\
\text { sebelum program) }\end{array}$ & 2,33 & 1,86 \\
\hline \multicolumn{4}{|c|}{ Kuesioner Post-test } \\
\hline 2 & Pelatihan ini bermanfaat & 3,58 & 3,36 \\
\hline 3 & Materi yang disampaikan menarik & 3,25 & 3,21 \\
\hline 4 & $\begin{array}{l}\text { Saya tidak bisa memahami materi yang } \\
\text { diberikan }\end{array}$ & 1,5 & 1,21 \\
\hline 5 & Pemateri terbuka dengan pertanyaan peserta & 3,58 & 3,21 \\
\hline
\end{tabular}


Vol. 2, No. 1, Juni 2021

\begin{tabular}{clcc}
\hline 6 & $\begin{array}{l}\text { Saya akan mempraktekkan pelatihan ini di } \\
\text { kehidupan sehari-hari }\end{array}$ & 3,17 & 3,07 \\
7 & $\begin{array}{l}\text { Keterampilan saya bertambah dengan adanya } \\
\text { pelatihan ini }\end{array}$ & 3,58 & 3,21 \\
\hline
\end{tabular}

Berdasarkan hasil dari kuesiner pre-test di Tabel 1 didapatkan hasil skala rata-rata peserta adalah 2,33 di mana pengetahuan mengenai pembuatan lilin sudah tahu. Hasil skala rata-rata untuk item-item pertanyaan kuesioner post-test ini berada di atas tiga. Hal tersebut menunjukkan bahwa para peserta setuju terhadap adanya manfaat pelatihan, penyampaian materi yang baik, keterbukaan pada pertanyaan, niat mempraktekkan dan penambahan keterampilan. Item pertanyaan post-test untuk ketidakpahaman pada materi yang disampaikan mempunyai skala rata-rata di bawah dua di mana para peserta dapat memahami materi pelatihan pengolahan minyak jelantah menjadi lilin aromaterapi. Pada saat sesi diskusi, para peserta menyatakan baru mendapatkan pengetahuan baru dalam membuat lilin dan berbeda dengan cara yang dulu pernah diketahui. Pelaksanaan dari tahap pelatihan pertama dapat dilihat pada Gambar 1 dan 2.

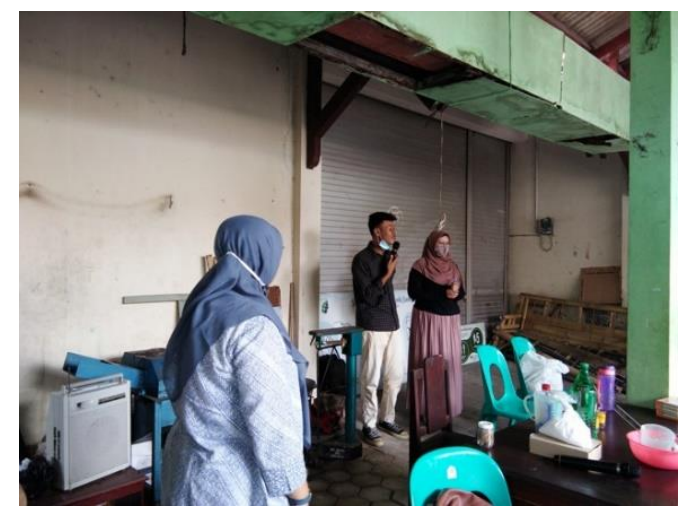

Gambar 1. Pemberian Materi Pelatihan Pengolahan Minyak Jelantah Menjadi Lilin Aromaterapi

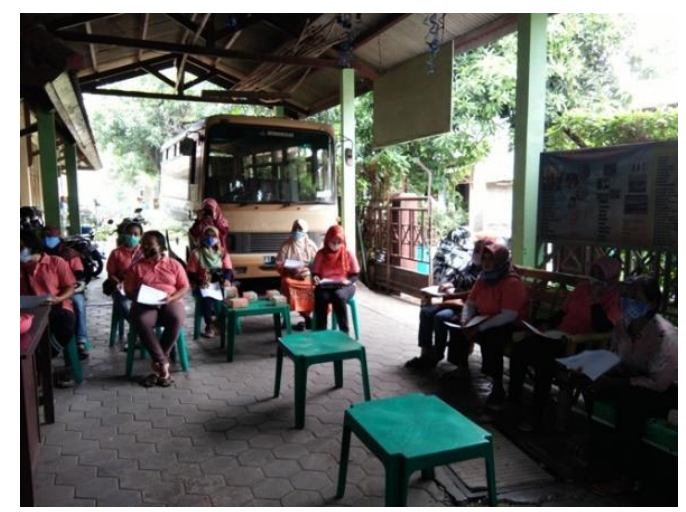

Gambar 2. Para Peserta Memahami Materi Pelatihan yang Diberikan

Tahap kedua dari aktivitas pengabdian kepada masyarakat adalah pelatihan dan pendampingan untuk kalkulasi Harga Pokok Produksi (HPP) dari lilin aromaterapi. Aktivitas tahap kedua terbagi menjadi tiga sesi yaitu pemberian materi mengenai konsep pembiayaan dan HPP, pelatihan perhitungan HPP dan pendampingan untuk menghitung 
Vol. 2, No. 1, Juni 2021

HPP lilin aromaterapi. Pemberian materi mengenai HPP merupakan dasar untuk para peserta mengetahui konsep dari pembiayaan dan jenis-jenis biaya. Sesi kedua fokus pada penggunaan dan perhitungan HPP dengan contoh yang dapat dipahami oleh para peserta. Contoh perhitungan yang diberikan menggunakan produk lilin dengan bahan-bahan serta alat yang dipakai pada pelatihan tahap pertama. Pada sesi terakhir merupakan pendampingan untuk menentukan HPP dari produk lilin aromaterapi dari bank sampah Lintas Winongo. Penentuan HPP ini diperhitungkan dengan melakukan simulasi untuk menentukan HPP produk lilin dengan beberapa pertimbangan dari biaya-biaya produksi dan biaya-biaya lain yang muncul dalam proses pengolahan. Pada simulasi perhitungan ini juga dicari beberapa alternatif untuk HPP dengan menggunakan bahan subtitusi pembuatan lilin. Di tahapan simulasi ini terjadi diskusi untuk mempertimbangkan harga produk pula dengan harga pasaran lilin. Diskusi dilakukan untuk menentukan bahan subtitusi dan wadah lilin yang lebih efisien agar tidak membebani biaya produksi.

Pada pelatihan tahap kedua juga diberikan kuesioner pre-test dan post-test kepada para peserta. Hasil dari pengolahan rata-rata skala jawaban dapat dilihat pada Tabel 1. Jumlah peserta untuk pelatihan tahap kedua mencapai 14 orang. Berdasarkan hasil kuesioner pre-test didapatkan nilai rata-rata sebesar 1,86 di mana menunjukkan para peserta kurang mengetahui kalkulasi HPP sebelum pelatihan. Pengetahuan mengenai HPP merupakan hal yang baru bagi anggota bank sampah Lintas Winongo. Selama ini produksi lilin tidak pernah memperhatikan biaya-biaya yang keluar dan HPP-nya.

Hasil dari kuesioner post-test pelatihan kedua didapatkan beberapa hal. Para peserta rata-rata setuju bahwa materi yang disampaikan bermanfaat. Penyampaian materi yang menarik dan ketidakpahaman pada penerimaan materi mempunyai rata-rata skala di bawah 2 sehingga materi dapat diterima. Keterbukaan pada pertanyaan saat pelatihan dirasa baik oleh para peserta. Kemudian pada item pertanyaan niat mempraktekkan dan penambahan keterampilan mempunyai nilai rata-rata di atas tiga sehingga para peserta mempunyai keinginan menggunakan pengetahuan HPP dan adanya keterampilan baru yang muncul. Pelaksanaan dari tahap pelatihan kedua dapat dilihat pada Gambar 3 dan 4.

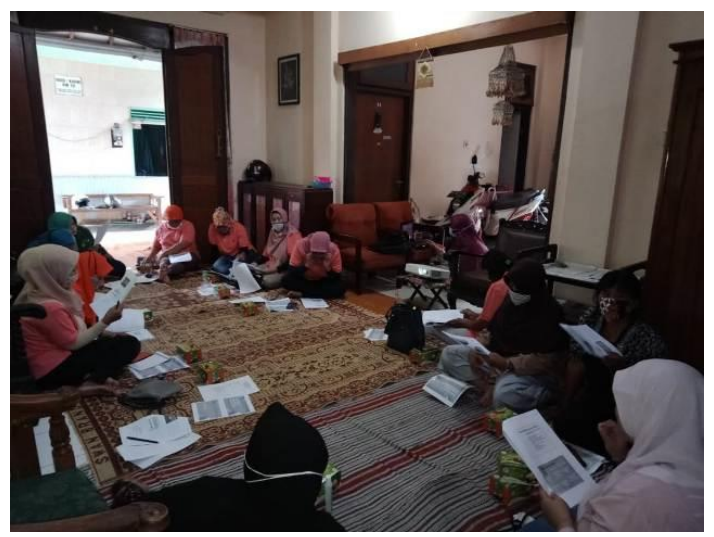

Gambar 3. Pemberian Materi Mengenai Konsep Pembiayaan dan HPP 
Vol. 2, No. 1, Juni 2021

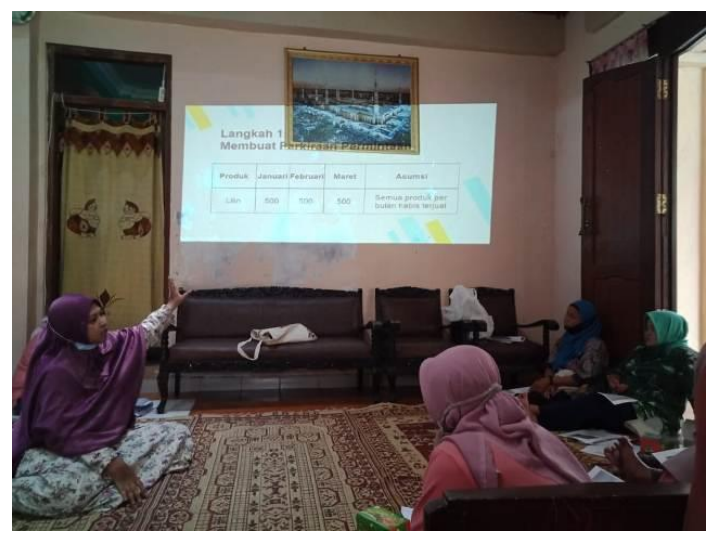

Gambar 4. Pelatihan dan Pendampingan Mengenai Perhitungan HPP dari Lilin Aromaterapi

Permasalahan yang ditemui mitra untuk mengolah minyak jelantah menjadi lilin dapat diberikan solusinya. Langkah-langkah baru dan bahan-bahan baru dalam pengolahan minyak jelantah menjadi lilin memberikan pengalaman belajar kepada anggota mitra program. Selain itu, para peserta juga menyatakan bahwa pelatihan HPP memberikan gambaran mengenai bagaimana mengelola pembiayaan dan penentuan harga produk merupakan hal penting.

\section{KESIMPULAN}

Aktivitas-aktivitas dalam program pengabdian ini memberikan manfaat pada anggota bank sampah Lintas Winongo. Tahapan aktivitas dalam program ini memberikan pengetahuan dan keterampilan baru tentang pengolahan minyak jelantah menjadi lilin aromaterapi serta perhitungan HPP-nya. Diharapkan dengan adanya program ini maka bank sampah Lintas Winongo mampu meningkatkan kemampuan untuk memproduksi lilin aromaterapi.

\section{UCAPAN TERIMA KASIH}

Terima kasih kepada Lembaga Penelitian dan Pengabdian kepada Masyarakat Universitas Ahmad Dahlan (LPPM UAD) yang memberikan pendanaan pada program ini. Terima kasih juga kami aturkan kepada pihak mitra yaitu bank sampah Lintas Winongo di Kelurahan Bumijo, Kecamatan Jetis, Kota Yogyakarta atas kerja samanya sehingga program ini dapat terlaksana dengan baik.

\section{DAFTAR PUSTAKA}

Adhani, A., \& Fatmawati. (2017). Pelatihan Pembuatan Lilin Aromaterapi dan Lilin Hias untuk Meminimalisir Minyak Jelantah bagi Masyarakat Kelurahan Pantai Amal. Jurnal Pengabdian Masyarakat Borneo, 3(2), 31-40.

Aini, D. N., Arisanti, D. W., Fitri, H. M., \& Safitri, L. R. (2020). Pemanfaatan Minyak Jelantah Untuk Bahan Baku Produk Lilin Ramah Lingkungan Dan Menambah Penghasilan Rumah Tangga Di Kota Batu. Warta Pengabdian, 14(4), 253-262. https://doi.org/10.19184/wrtp.v14i4.18539

Artwohl, M., Roden, M., Waldhäusl, W., Freudenthaler, A., \& Baumgartner-Parzer, S. M. (2004). Free fatty acids trigger apoptosis and inhibit cell cycle progression in human vascular endothelial cells. The FASEB Journal: Official Publication of the 
Vol. 2, No. 1, Juni 2021

Federation of American Societies for Experimental Biology, 18(1), 146-148. https://doi.org/10.1096/fj.03-0301fje

Astuti, A., Linarti, U., \& Yulistiyanto, M. (2019). Identifying Waste Cooking Oil Chains to Become an Energy Resource: Study Case in Yogyakarta. Advances in Intelligent Systems Research, 171, 228-236. https://doi.org/10.2991/icoemis-19.2019.32

Azahar, W. N. A. W., Bujang, M., Jaya, R. P., Hainin, M. R., Mohamed, A., Ngadi, N., \& Jayanti, D. S. (2016). The potential of waste cooking oil as bio-asphalt for alternative binder - An overview. Jurnal Teknologi, 78(4), 111-116. https://doi.org/10.11113/jt.v78.8007

Budiarti, G. I., Wulandari, A., \& Mutmaina, S. (2020). Pemanfaatan Tepung Labu Kuning Modifikasi Hydrogen Rich Water Kepada Masyarakat. SPEKTA (Jurnal Pengabdian Kepada Masyarakat: Teknologi Dan Aplikasi), 1(1), 11. https://doi.org/10.12928/spekta.v1i1.2646

Budiyanto, T., Astuti, R. D., \& Purwani, A. (2020). Pelatihan Dan Pendampingan Pengolahan Sampah Menjadi Produk Bernilai Ekonomi Pada Bank Sampah Bersih Bersama Karanganom, Sitimulyo, Piyungan, Bantul. SPEKTA (Jurnal Pengabdian Kepada Masyarakat: Teknologi Dan Aplikasi), 1(2), 49. https://doi.org/10.12928/spekta.v1i2.3044

Delta. (2021). PEMANFAATAN MINYAK JELANTAH (Waste Cooking Oil) DALAM PEMBUATAN LILIN AROMA TERAPI. Jurnal Kesehatan Luwu Raya, 7(2), 127132.

Jamilatun, S., Mulia Sitophyta, L., Amelia Universitas Ahmad Dahlan, S., Ringroad Selatan, J., \& Banguntapan, K. (2020). Pemanfaatan minyak jelantah untuk pembuatan lilin sebagai alternatif mengatasi limbah domestik dan meningkatkan nilai tambah. Seminar Nasional Hasil Pengabdian Kepada Masyarakat, 0(0), 4956.

Kuo, C. Y., \& Ann, D. K. (2018). When fats commit crimes: Fatty acid metabolism, cancer stemness and therapeutic resistance. Cancer Communications, 38(1), 1-12. https://doi.org/10.1186/s40880-018-0317-9

Lupi, R., Dotta, F., Marselli, L., Del Guerra, S., Masini, M., Santangelo, C., ... Marchetti, P. (2002). Prolonged Exposure to Free Fatty Acids Has Cytostatic and Pro-Apoptotic Effects on Human Pancreatic Islets. Diabetes, 51(5), 1437-1442.

Madak-Erdogan, Z., Band, S., Zhao, Y. C., Smith, B. P., Kulkoyluoglu-Cotul, E., Zuo, Q., ... Flaws11, J. A. (2019). Free fatty acids rewire cancer metabolism in obesityassociated breast cancer via estrogen receptor and mTOR signaling. Cancer Research, 79(10), 2494-2510. https://doi.org/10.1158/0008-5472.CAN-18-2849

Oh, Y. S., Bae, G. D., Baek, D. J., Park, E. Y., \& Jun, H. S. (2018). Fatty acid-induced lipotoxicity in pancreatic beta-cells during development of type 2 diabetes. Frontiers in Endocrinology, 9(JUL), 1-10. https://doi.org/10.3389/fendo.2018.00384

Sanli, H., Canakci, M., \& Alptekin, E. (2011). Characterization of Waste Frying Oils Obtained from Different Facilities. Proceedings of the World Renewable Energy Congress - Sweden, 8-13 May, 2011, Linköping, Sweden, 57, 479-485. https://doi.org/10.3384/ecp11057479

Saragih, S. (2015). Gentayangan di Jakarta, Badan POM Ungkap Modus Mafia Minyak Jelantah.

Sundoro, T., Kusuma, E., \& Auwalani, F. (2020). Pemanfaatan Minyak Jelantah Dalam Pembuatan Lilin Warna-Warni. Jurnal Pengabdian Masyarakat Ipteks, 6(2), 127136. 
Vol. 2, No. 1, Juni 2021

Tsai, W. T. (2019). Mandatory recycling of waste cooking oil from residential and commercial sectors in Taiwan. Resources, 8(1), 1-11. https://doi.org/10.3390/resources8010038

Vanessa, M. C., \& Bouta, J. M. F. (2017). Analisis Jumlah Minyak Jelantah yang dihasilkan Masyarakat di Wilayah JABODETABEK. Politeknik Manufaktur Negeri Bangka Belitung, (January), 1-21.

Wardani, D. T. K., Saptutyningsih, E., \& Fitri, S. A. (2021). Ekonomi Kreatif: Pemanfaatan Limbah Jelantah Untuk Pembuatan Lilin Aromaterapi. Prosiding Seminar Nasional Program Pengabdian Masyarakat, 402-417. https://doi.org/10.18196/ppm.32.224

Wee, H. M., Budiman, S. D., Su, L. C., Chang, M., \& Chen, R. (2016). Responsible supply chain management - an analysis of Taiwanese gutter oil scandal using the theory of constraint. International Journal of Logistics Research and Applications, 19(5), 380-394. https://doi.org/10.1080/13675567.2015.1090964 
SPEKTA

Jurnal Pengabdian Kepada Masyarakat : Teknologi dan Aplikasi

Vol. 2, No. 1, Juni 2021

Halaman ini sengaja dikosongkan

This page is intentionally left blank. 